\title{
Traditional Values of Eastern Finno-Ugrians as Evidenced in Proverbs and Sayings
}

\author{
Natalia N. Glukhova ${ }^{1}$, Raisiya A. Kudryavtseva ${ }^{1}$, Rodion I. Chuzaev $^{1} \&$ Galina E. Shkalina ${ }^{1}$ \\ ${ }^{1}$ Mari State University, Yoshkar-Ola, Russia \\ Correspondence: Natalia N. Glukhova, Institute of National Culture and Intercultural communication, Mari State \\ University, Kremlyovskaya Street 44, Yoshkar-Ola, 424002, Russia.
}

\author{
Received: February 21, 2015 Accepted: March 15, 2015 Online Published: April 29, 2015 \\ doi:10.5539/res.v7n8p156 URL: http://dx.doi.org/10.5539/res.v7n8p156
}

\begin{abstract}
The objective of the article is to reveal and describe the value systems of the Komis, Maris, Mordvins and Udmurts as reconstructed from the folklore genres of proverbs and sayings of the ethnic groups under discussion. The authors apply a complex technique to 13820 proverbs taken from specialized dictionaries published in the four corresponding republics. The strategy involves the use of semantic analysis as well as quantitative evaluation carried out with the help of a linear correlation coefficient. The algorithm of the investigation consists of several steps. The most important stage includes the process of discerning values, called "factors", from proverbs and sayings with the help of componential and contextual types of analysis. Statistical methods revealed the most important eight values common to the four eastern Finno-Ugrian ethnic groups which are arranged in a descending order of their number and frequency of occurrence. The findings of an investigation into traditional axiology are also presented with the help of graphical metalanguage — as the tabulated data and in the form of diagrams.
\end{abstract}

Keywords: Finno-Ugrians, Komis, Maris, Mordvins, Udmurts, value, factor, semantic analysis, quantitative evaluation, graphical metalanguage

\section{Introduction}

The prime objective of the research is to define the traditional values of the Maris, Mordvins, Komis and Udmurts thus showing (non-material) cultural affinity of the Finno-Ugrian ethnic groups under study. As culture encompasses many components the comparison of even two cultures represents a complicated task. But by comparing not all elements but only value systems the task can be accomplished. We hypothesize that the main ideas and principles of any ethnic culture are expressed in its values.

There are universal moral standards and norms, but the importance and systemic ties among them vary within each culture. The value systems of different peoples are not the same. Thus, for example the U. S. value list includes such priorities as "change", "time and its control", "equality", "individualism and privacy", "self-help concept" "action orientation", "informality", "practicality and efficiency" and others in addition (Robert, 2011). In other investigation the values overlap with this list but researchers add "achievement and success", "activity and work", "efficiency and practicality", "process and progress", "material comfort" and others (Williams, 1970); "moral purity", "hard work", "sobriety", "education", "self-discipline", "self-improvement" and others (Kang, 2009). According to sociological questionnaires basic values of peoples of Eurasian civilization are "collectivism", "stability" and "permanency", "cooperation/collaboration", and not "rivalry" and "competition", "family", "health", "education" (Popkov, 2009).

It is important to define Finno-Ugric ethnic basic values as the social structure and the economic system in Russia are nowadays being transformed under globalization processes. Such changes usually affect the lives of people, their aspirations and goals. As is known the continuity and development of a value system form the basis of ethnic culture, therefore their study in systemic ties, revealing the correlation of dominant and peripheral values is considered of current importance. Investigation into four Finno-Ugric cultures, research on their axiological paradigms with their values systems fixation, helps on the one hand to reveal the core elements of ethnic identity, showing the degree of cultural affinity, and - on the other, to create the basis for effective intercultural communication and the integration of ethnic groups into a polycultural world. 
The traditional value system of any ethnic group is expressed in one way or another by folklore. There are many folklore genres reflecting different aspects of the life of the ethnic groups in question: songs, legends, myths, narratives, prayers, charms, riddles, and folktales. We offer the hypothesis according to which ethnic systems of values are embodied in proverbs and sayings as they, being a separate folklore genre, contain accumulated folk wisdom and generalized observations of all phenomena of the ethnic group's life expressed in the most succinct form. Being statistically reliable authentic material, proverbs and sayings represent highly illustrative and plausible evidence as they have been used by Finno-Ugrians for hundreds of years. The results of investigation of 13820 proverbs from seven dictionaries available to us (Grachyova, 2001; Ibatov, 1960; Kitikov, 2004; Paczolay, 1987; Perevozchikova, 1987; Plessovskii, 1983; Samorodov, 1967) are discussed in this paper.

Research has shown that among the paroemiological stocks of the four Eastern Finno-Ugrian nations there are proverbs and sayings containing various values, such as "happiness", "quiet life", "good and evil", "freedom", "beauty", "love", "sin" etc. But the most numerous and frequently used proverbs and sayings in the folklore cultures of these four Finno-Ugric groups have been subsumed into eight completely similar groups, thus providing consistency between ethnic groups. These values are: ethics, knowledge, labor, family, speech (language), wealth, food, and health.

There are articles and portions of monographs dedicated to the definition of the value systems of Finno-Ugrians which have been carried out either with the analysis of ethnic literary works or historical and folklore material (Chuzayev, 2011; Chuzayev, 2012; Glukhova \& Kudryavtseva, 2013; Shkalina, 2003; Shkalina, 2011), or based on the results of sociological questionnaires (Shabykov \& Kudryavtseva, 2014). The results of this research work confirm the results described in this paper.

Though the distinct eight values are present in the cultures common to all mankind, the Finno-Ugrian ethnic groups differ from other nations and one another either by order of priority among these standards or by sheer coincidence in such a sequence. To define the degree of Finno-Ugric affinity the authors resort to a system of methods and techniques which was applied to folklore texts for the first time to outline a traditional Mari ethnic identity (Glukhov \& Glukhova, 2012) and is now being used to reveal the cultural affinity of the values systems of four Finno-Ugrian ethnic groups.

\section{Methods}

The algorithm of the research, combining methods and stratagems from linguistics (componential and contextual analyses) and, systems theory, which in turn involves factor and statistical analysis (the principle of a simple majority of a dichotomous method), consists of several stages.

In the initial stage of the research folkloristic texts were read and analyzed semantically with the aim of determining values (called "factors"). Research has shown, that the analyzed proverbs and sayings are used both in their literal and figurative meanings. Folklore maxims have been chosen in two ways, according to two principles. Either the entire figurative meaning of the proverb is devoted to a certain value, or there are separate lexemes showing something important or useful in people's lives, making the meaning of the proverb literal. The more important a value is, the more often it is mentioned in the proverbs, or there are more texts the whole meaning of which is dedicated to this or that value in the paroemiological stock of the ethnic group. This fact allows the ranking of values in a descending order of their occurrence.

After the compilation of lists of proverbs to be analyzed the value incidence was esteemed and the probability of value usage was calculated. The data was then further presented in tables.

The next stage was devoted to the preparation of diagrams with the ranking of values in a descending order of probability. The differential diagram consists of columns positioned above and below the horizontal axis depicting how the values mentioned can have both positive and negative connotations. In the summarizing diagram each factor is shown as a separate column with a height proportional to its probability of occurrence (shown in the tables). The columns are arranged in descending order. Furthermore the numerical data to which a dichotomous method is applied help to discern four groups of values. They can conventionally be divided into main, complementary, auxiliary, and insignificant. Then correlation coefficients were calculated and a matrix of values was compiled. The investigation into traditional Finno-Ugric axiology concludes with a summarization of the results (Glukhov \& Glukhova, 2011).

Thus, the essence of the method employed lies in the distribution of the analyzed proverbs into groups showing values and the calculation of value mention in each group. The number of different values will differ in paroemiological thesauruses of each ethnic group depending on their importance to the people. Ranking helps in turn to compile a system of priorities for an ethnic group, to differentiate values by their meaning and to forecast 
their choice in concrete situations.

As has already been mentioned, factor analysis reveals the most numerous and frequently used values in proverbs and sayings which have been assigned to eight similar groups important in the traditional cultures of the Komis, Maris, Mordvins and Udmurts. They are: ethics, family food, health, labor, knowledge, speech (language), and wealth enumerated here in alphabetical order. The research has also shown that each value manifests itself in two ways: positively and negatively. Therefore, value mention was carried out separately with two signs: a minus sign and a plus sign fixed in the tables and in differential diagrams.

This part of research procedure was carried out for each ethnic group. The averaged probability distribution of values is shown in Table 5 and graphically rendered in Figure 5.

\section{Results}

\subsection{The Maris}

An analysis of 3590 proverbs and sayings (Grachyova, 2001; Ibatov, 1960; Kitikov, 2004) showed the following ranking of values expressed in Mari proverbs: ethics, family, knowledge, speech, wealth, food, labor, health. The most significant of these are ethics, family and knowledge. The second group constitutes speech, wealth, and food. In this article we will show examples illustrating the traditional Finno-Ugrians' values of the first, dominant group.

Mari proverbs and sayings condemn violence (Лепка лепкам шелеш "lit."One forehead breaks another" (there is always someone who is much stronger)". Маска виян, да тудымат кучат "Bears are strong but they get caught, too"); laziness (Тачеш яра, эрлажым ояра "Today we are free, and tomorrow it will be clear (the day

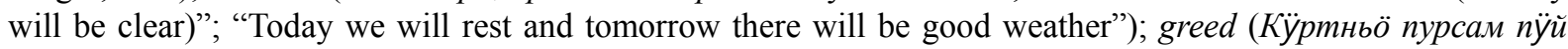
дене пурлаш огеш лий lit. "Iron peas can't bitten through by teeth"); lies, deception (Тангетым ондалет, шкеат ондалалтат "If you deceive your friend, you will deceive yourself”); stupidity (Умдымо вуй йоллан неле "An empty (silly) head is heavy for the feet"); cowardice (Ораде кайык-иамыц кукум варашлан шотлат "Silly birds take a cuckoo for a hawk"); theft (Шольитммаш-чон иомдарымаш "Theft is a loss of the soul"); епvу (Кугу да енгын, изи да шкемын "A big 'but' is someone else's, a small 'but' is one's own”); heavy drinking, drunkenness (Арака логарлан ильш тӱрволакеш кержалтше ийсӱс “A drunkard's life is like an icicle hanging off a roof end"); ingratitude (Ү̈стел коклашке сӧснам шынде, йолжымат ӱстембаке nbluma "Sit a pig down to table, and it will put its legs on it").

The factor "Family" occupies the second place in the hierarchy of values: Ик кидкок кидлан ок шу, шкет ильли ильилан ок шу "One hand will not replace two (hands), a solitary life will not replace a family". People think that it is much easier to survive when you have a family. (In the proverbs large extended families are meant): "Кугу (тӥшка) еш дене илаш куштылго "It is easy to live in a big family". And: Aча-aватылм жаплет гын, кужу ӱмыран лият "If you respect your parents you will live a long and happy life". Founding a family is not easy: "You need money for a whole house to get married". One should not hurry to get married: "Don't feel sorry that you got up early, be sorry that you got married too young" as "A girl's life is a life of honey, a married woman's life is a dog's life". Unmarried men get an unflattering reference in proverbs: Bambldblмe марий вӥдым кычалше комбо гай “A man without a wife is like a goose seeking water". People think that "The head of the family is a man" though a woman's role in the family is not belittled: Baте пойдара, вате йомдара, вате-сурт менге "A wife may enrich and may impoverish, a wife is the backbone of the house". The birth of children in the family is a new stage of interrelations in a complex hierarchy in a big extended family. Relationship with relatives by birth is also unequal, but it becomes even more complicated when children grow and get married themselves: Ү̈дыр-венгыч дене-полан когыльо, эргыч-иешкыч дене-иинчалан когыльо "Daughter and son-in-law have vibernum berry pies, son and daughter-in-law have salty pies". Or: "With a daughter and son-in-law it's like a berry pie, with a son and daughter-in-law it's like a salty pie".

Next in a descending order of priorities is the factor "Knowledge". It is considered that "Knowledge is the greatest wealth" Шинчымаш-эн кугу поянлык. Knowledge as well as skills are passed on from one generation


is a host and knowledge is a guest". The proverbs analyzed underline ties between the mind and studying: Шуко ильше огыл, иуко тунемше шуко шинча "He knows much who has studied much but not who has lived long". In people's opinion knowledge might be acquired by:

1) Learning something from more experienced and informed people: Мом моштет-енгым туныкто, мом от иинче- -иинчыше деч тунем “Теасh others what you know yourself, learn from others what you don't know”;

2) Traveling: Мӱндыр мланде ушылм пурта "Distant lands bring knowledge"; 
3) Reading books: Книгӓ-пӓльмӓи коловец “A book is a well of knowledge"; Шуко лудат-шуко палет "When you read much you know much". But studies are not easy and knowledge is difficult to acquire: $Y u$ паша-неле паша: вӥрым локтылеш, йыжынгым тодеш "Mental work is difficult work: it spoils the blood and makes the joints ache". Not all the information read in books is useful, therefore proverbs and sayings give skills and wits an equal assessment: "It is not knowledge that is precious but skills".

Then come the factors "Speech", "Wealth", "Food". They are used both with positive and negative connotations. The list of priorities is completed by such values as "Labor" and "Health".

The data obtained is presented in Table 1 .

Table 1. Averaged probability distribution of values mentioned in Mari proverbs and sayings

\begin{tabular}{llccc}
\hline No & Value & $\begin{array}{c}\text { Probability of usage with } \\
\text { positive evaluation “+” }\end{array}$ & $\begin{array}{c}\text { Probability of usage with negative } \\
\text { evaluation “-” }\end{array}$ & $\begin{array}{c}\text { Sums } \\
\text { probability }\end{array}$ \\
\hline 1 & Ethics & 0.077 & 0.147 & 0.224 \\
2 & Family & 0.097 & 0.054 & 0.151 \\
3 & Knowledge & 0.107 & 0.038 & 0.145 \\
4 & Speech & 0.051 & 0.057 & 0.108 \\
5 & Wealth & 0.068 & 0.038 & 0.106 \\
6 & Food & 0.082 & 0.02 & 0.102 \\
7 & Labor & 0.05 & 0.038 & 0.088 \\
8 & Health & 0.038 & 0.038 & 0.076 \\
& Sums & 0.570 & 0.430 & 1.000 \\
\hline
\end{tabular}

The results shown in Table 1 are graphically represented in Figure 1. 

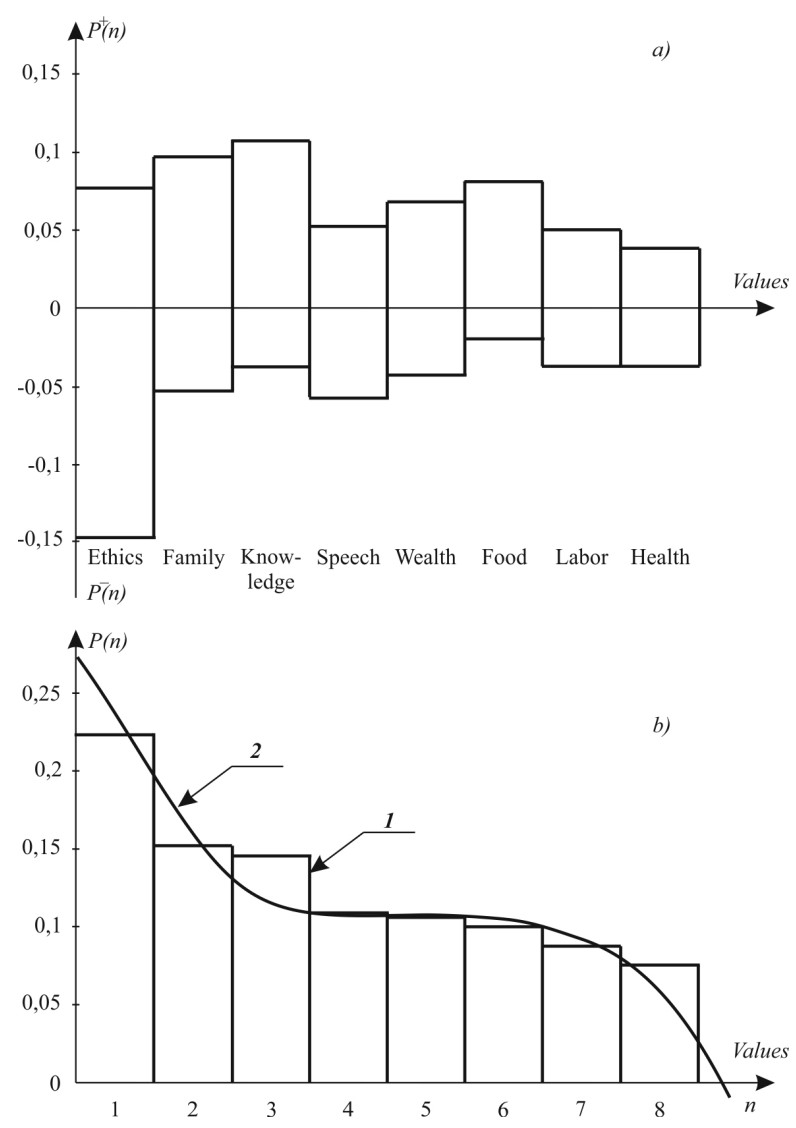

Figure 1. Differential (a) and summarizing (b) diagrams showing the averaged value-mention probability distribution in Mari proverbs and sayings

\subsection{The Mordvins}

As revealed by the analysis of 3250 proverbs and sayings given in the dictionaries in two language variants shown here as well (Kitikov, 2004; Samorodov, 1967), the Mordvins esteem the following values most of all: ethics, speech, knowledge, family, labor, food, wealth and health. The main group embraces such values as ethics, speech, and knowledge. Probability of the enumerated values occurrence are tabulated in Table 2.

Table 2. Averaged probability distribution of values mentioned in Mordvin proverbs and sayings

\begin{tabular}{clccc}
\hline No. & Value & $\begin{array}{c}\text { Probability of } \\
\text { usage with positive } \\
\text { evaluation } \\
\text { "++" }\end{array}$ & $\begin{array}{c}\text { Probability of usage with } \\
\text { negative evaluation } \\
\text { “_”" }\end{array}$ & Sums probability \\
\hline 1 & Ethics & 0.112 & 0.132 & 0.244 \\
2 & Speech & 0.071 & 0.07 & 0.141 \\
3 & Knowledge & 0.092 & 0.046 & 0.138 \\
4 & Family & 0.101 & 0.024 & 0.125 \\
5 & Labor & 0.087 & 0.037 & 0.124 \\
6 & Food & 0.063 & 0.014 & 0.077 \\
7 & Wealth & 0.041 & 0.035 & 0.076 \\
8 & Health & 0.034 & 0.041 & 0.075 \\
& Sums & 0.601 & 0.399 & 1,000 \\
\hline
\end{tabular}


As in the case with Mari proverbs the tabulated data is shown in the form of two diagrams.
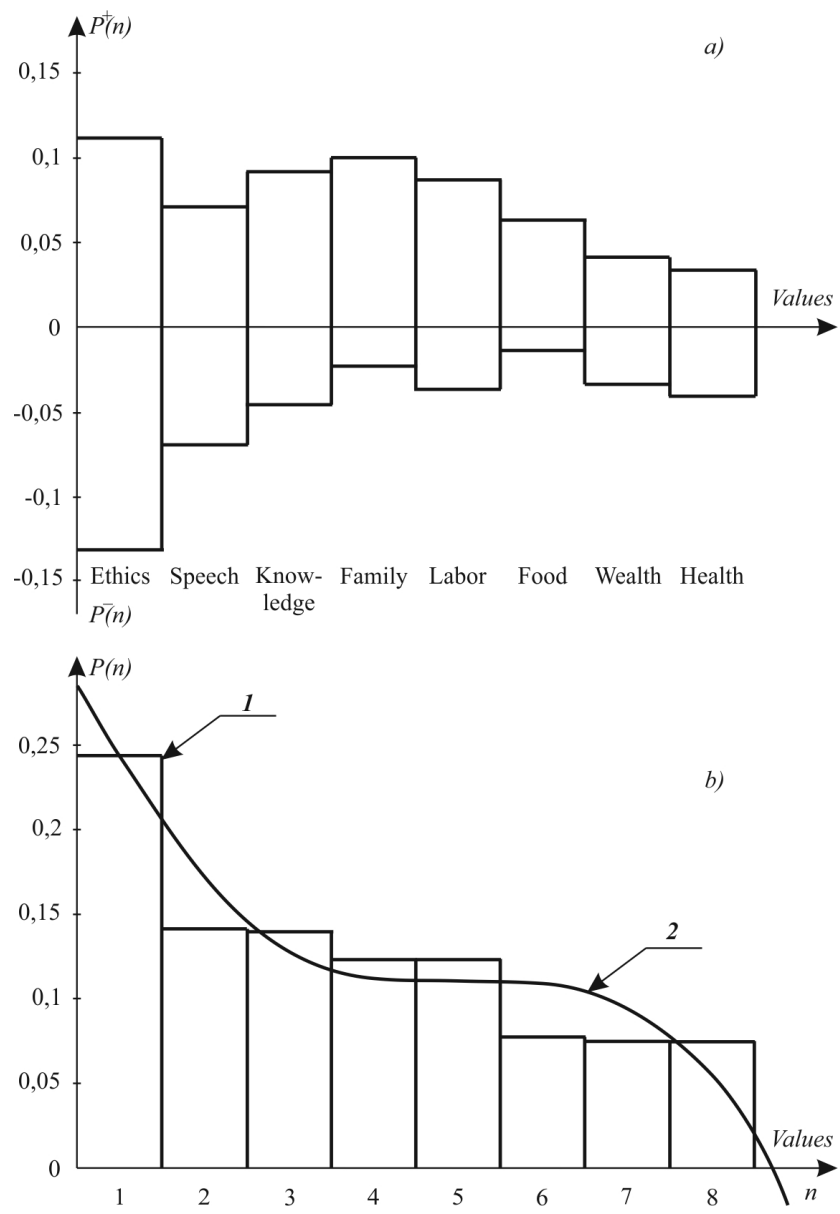

Figure 2. Differential (a) and summarizing (b) diagrams showing the averaged value-mention probability distribution in Mordvin proverbs and sayings

"Ethics" occupies the first place in the diagram. The summarizing column of the factor "Ethics" is larger than the rest of the columns in the diagram. It shows that ethics is of primary importance for this ethnic group. The same significance to this factor is attached by the Mari people.

Of all ethical vices in the analyzed proverbs and sayings violence is criticized most of all (Kда парста meвcь аф тиеви, кяжса-ёфси literal: "If you can't achieve anything by doing it in a good way, you will never do it by malice”), laziness (Нолать фалу пекои сяряди. Лодырень яла пекезэ сэреди (lit.: “A lazy person always has a stomach ache"), avarice (Козянь кядьста тялонда лов а фанат. Сюпавонь кедьстэ тельня лов поколь а вешат lit. "A rich man will not give snow even in winter"), theft (Вор мархта якат-воронди альнякат (вор и улят). Сальия марто якат-сальия улят lit.: "If you are in the company of thieves you yourself will be a thief"), lies, decерtion (Васькафнезь эрят-эсь кицень перят. Манчезь кувать а эрят lit.: "You will not live long on deception"; "You can't live all your life deceiving"; Аф видешиса эрямс-эстейть кись перямс lit.:"Living in lies means killing oneself”), stupidity (Ёньфтема корхтай кяль-аньцек колай мяль. Тевтеме лапныця келесь-чаво парьсэ лаужа lit. "Say something silly and you will show your stupidity"), cowardice (Пелят аф эсь кигат кялят lit. "If you are afraid, that means you have chosen the wrong way"), ingratitude (Лама парда тият-лама ялгат муят. Ламо паро теят-ламо ялгат муят lit. "If you do much good you will find many friends"), heavy drinking (Ирецтоньшись (симондемась) цебярьс аф вяти literal "Неavy drinking will not lead to anything good"), епvу (Ломань париис лама сельмода lit. "Many eyes watch other people's property). 
The factor "Knowledge" together with the factor "Speech", occupy the second and third places in the analyzed texts respectively. They have the same height of columns. The diagram shows the positive estimation of this factor. Knowledge is associated with the mind. People think: Первей ломанесь прок лисьмапря lit. "A clever man is like a well", as "Without thinking one can drown in a dry swamp". The best knowledge source is life itself "Life is the best teacher"; "When you build a house, you will acquire knowledge". But you can acquire it by reading books "Books give wings". Proverbs and sayings stress the fact that one can gain knowledge by asking questions: Ки ланга ломать кизе-фнятпиьлкент зря аф сизефнят "When travelling ask more about the way, then your feet will get less tired". Knowing that "Man's mind is a mighty power" helps you avoid making mistakes in life, be prudent: Молят фкя шись, кии сяфть неделяс "If you go for a day, take bread for a week".

Proverbs and sayings reflecting people's attitude towards speech, note the connection of thoughts with words: Кодама мялсь, стама кяльсь. Кодамо мелесь, истямо келесь "What you think, that you say"). They advise to be reserved: Васенда арьсек (кулихонтт), тоса вал аст (корхтак). Васня кулсонок, мейле кортак (ёвтак) "First, listen, and then speak". Besides, as is known "Келянть" аламазо а сизи (lit. "The tongue is boneless and is never tired") and may hurt an interlocutor: Кяльсь пеельдонга оржа lit. "The tongue is sharper than the knife". "The tongue is boneless but breaks bones".

\subsection{The Komis}

In this part of the paper we analyze proverbs and sayings collected and systematized by F. V. Plessovskii in his work "Коми мойдъяс, сьыланкывъяс да пословицаяс" (Plessovskii, 1956), and A. E. Kitikov in his dictionary "Proverbs and Sayings of Finno-Ugrians" (Kitikov, 2004).

The investigated material (3480 proverbs) showed that the most important Komi values are: ethics, family, knowledge, labor, food, speech wealth and health. Ethics, family and knowledge constitute the main value group.

Ethical vices and moral flaws in Komi society criticized in proverbs and sayings are arranged in the following order of frequency of occurrence: laziness ("A lazy person is too lazy even to say the word "laziness"), violence, aggression ("You can't breed a lamb from a wolf"), lies ("Boasting is not mowing: the back will not be overstrained"), greed ("To ask something from him is the same as getting a crumb from a mouse's mouth"), theft ("There are no locks against a thief in the house"), heavy drinking ("You can't build a house by drinking"), stupidity ("Don't sell your stupidit—nobody will buy it"), cowardice ("A scared bear is afraid of a stump"), ingratitude ("A taking hand is long, a giving hand is short"), envy ("The butter is thicker on the bread in another person's hand").

Second place by importance is occupied by the factor "Family": Сюмӧдыл век кильлан (кусыньтчӧ) "lit. Birch bark always rolls up in itself", meaning "You always help your own". Proverbs note that a calm harmonious relationship among members of the family helps us to live peacefully: Корсемья костые совет да любовь, сэки и шыньгы ов "When there is love and concord in the family, then it is easier to live". Love and a friendly attitude towards each other favorably affect the children's upbringing: Бадьты кӧ пармӧй, и ныв-пиыд пармёиӓсь (Батьыьд кӧ, и ныв-пиаьлд прамӧйӧсь) “A good father has good children”. Popular wisdom gives advice: Челядьтӧ жалит да игла эн петк-для "Feel sorry for children, but don't show it to them". One should not resort to violence dealing with children: Челядьтӧ колӧ, велӧдны лекӧн немтор он бость "Children should be taught without violence, nothing will be attained by force". The Komis observe that: Челядь бать-мам бурлуннас и лёклуннас "Children will be either kind or ill-natured taking after their parents". It has also been known that "Вӧрад пуыс абу ӧткодь, сьэмя пытиккын йӧз абу ӧткодь "Trees in a forest are different, people in a family are also dissimilar". But children may resemble their parents therefore there is a whole list of maxims devoted to the topic of similarity: Кутшӧм сюрӧм пуыс сэтшӥм да пельӧм чапйыс lit. "Like an old tree, like a chip"“Like a chip off the block". Кутиӧм вӧр-пу, сэтиӧм и ув-бадь "Like trees, like brushwood", meaning: "Like parents, like children". Family life cannot always be conflict-free: Сира-пыжа коласас эн сюйсвы lit. "One should not try to get between a boat and tar"- "It's not advisable to interfere in another family's life". Under such circumstances the children's fate is different: Кык кытад вотӧм кагаылд пельтӧм "When there is discord between parents a child grows up naughty (lit. stupid)". As is known, if you do not listen to the parents' advice there might be problems: Бать-мамтӧ кӧ он кывзы, шыльча йылын бергалан "Disobey your parents and you will whirl on the awl";', If you don't obey your parents you will wander at loose ends". Life with parents is highly esteemed: Отвыльин олигӧн шад роковыдсукджык "Even porridge is thicker in a big family", Мам борд ульын олигӧн оза босьтльь "Under your mother's wing you will not learn what grief is". But one can't always live with one's mother and father: Мам борд улад ӧд нэмтӧ он ов "You can't live your whole life under your mother's wing". There are many proverbs and sayings describing the mother-child relationship: Челядьлӧн 
быд шогыс, был дольжысс инмӧ медвдз мам сьӧльмӧ “A child's sorrow and joy touch a mother's heart”, but Из вылӧ кӧрт вылӧ челядь ысллӧн, мамыслӧн-челядыьс вылӧ “A mother always thinks of her children, but a child's heart can turn into stone or iron". Despite the important role of a woman in family life which is shown in proverbs and sayings the maxim Кал моль орӧм кодь бабаьлдӧн кулӧмыл “A wife's death is equal to the loss of a trouser button" is quite discordant.

Next comes the factor "Knowledge". It is believed that it is necessary to study constantly: Век ов ивеквелӧдчы "Live a century-learn a century" ("It is never too late to learn)". Though experience can be bitter: Петлӧ сесся ньӧддзӧ варччыны "It is enough for me, I have bitter experience" (lit. "It is enough to always swim to mud"). Sometimes it is useless to teach people: Сийос велӧдны-ловпу нюкыльтны "Tеaching him is the same as bending an alder-tree”. Studies and learning are related in Komi proverbs with traveling: Ветльсь-мунысь мортыл уна юысь васӧ юӧ "A traveling man drinks water from many rivers". Studies are of exceptional significance to the young: "Studies are as important to the young as food to a hungry man". Knowledge and skills bring people wealth: Зиль мортль низьылд-мойыд керка пельӧсӧдыс кайӧ "Beavers and sables come to the house of a skilled hunter"; Сямлуныс кыйсьыскӧн ноп сертиыс тылдалӧ "A hunter's experience is seen by his knapsack"; Черитӧ бӧж дорнад он кый "If you get the hem (of your pants) wet, you'll eat fish".

The results of the analyzed Komi texts are presented in Table 3.

Table 3. Averaged probability distribution of values mentioned in Komi proverbs and sayings

\begin{tabular}{clccc}
\hline No. & Value & $\begin{array}{r}\text { Probability of usage } \\
\text { with positive evaluation “+” }\end{array}$ & $\begin{array}{c}\text { Probability of usage with } \\
\text { negative evaluation “_” }\end{array}$ & Sums probability \\
\hline 1 & Ethics & 0.067 & 0.145 & 0.212 \\
2 & Family & 0.098 & 0.06 & 0.158 \\
3 & Knowledge & 0.096 & 0.037 & 0.133 \\
4 & Labor & 0.075 & 0.054 & 0.129 \\
5 & Food & 0.082 & 0.027 & 0.109 \\
6 & Speech & 0.037 & 0.066 & 0.103 \\
7 & Wealth & 0.038 & 0.055 & 0.093 \\
8 & Health & 0.027 & 0.036 & 0.063 \\
\end{tabular}

These considerations are summarized pictorially in Figure 3. 

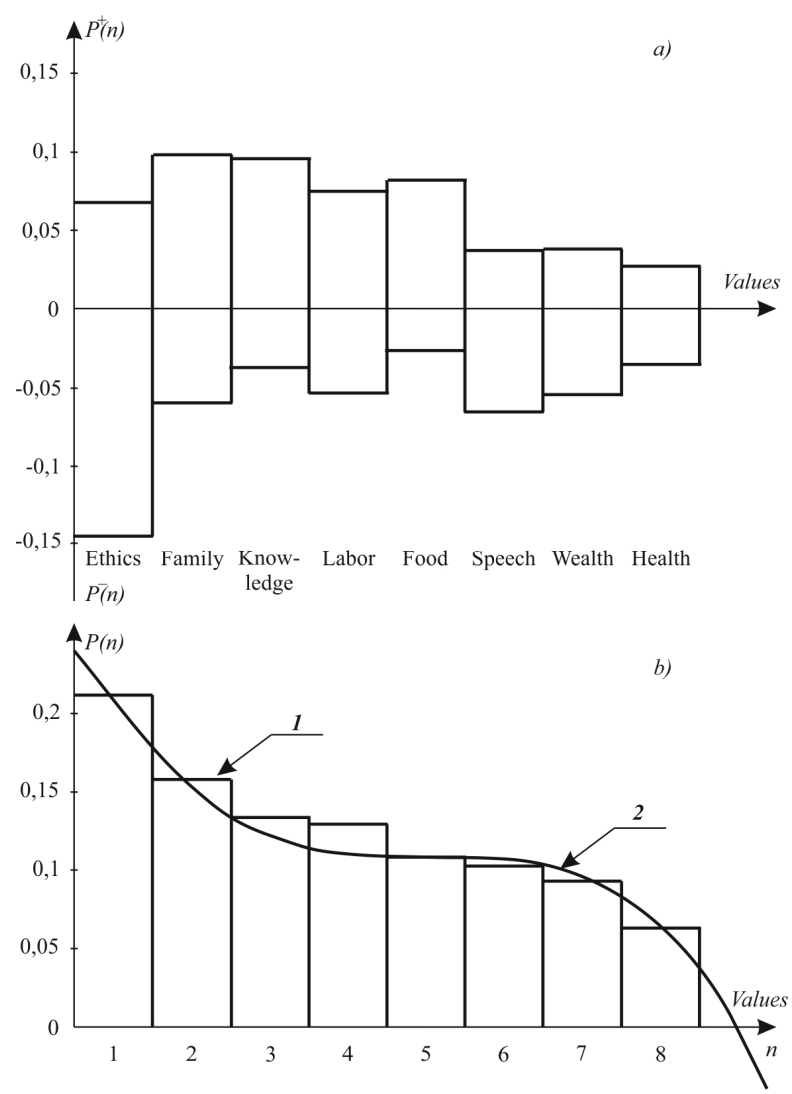

Figure 3. Differential (a) and summarizing (b) diagrams showing the averaged value-mention probability distribution in Komi proverbs and sayings

\subsection{The Udmurts}

Analysis of 3500 Udmurt proverbs (Kitikov, 2004; Perevozchikova, 1987) showed that the most important Udmurt values are: ethics, knowledge, labor, speech, family, health, food and wealth. As in previous cases, the results of the analysis are tabulated in Table 4.

Table 4. Averaged probability distribution of values mentioned in Udmurt proverbs and sayings

\begin{tabular}{clccc}
\hline No & \multicolumn{1}{c}{ Value } & $\begin{array}{c}\text { Probability of usage with } \\
\text { positive evaluation “+” }\end{array}$ & $\begin{array}{c}\text { Probability of usage with } \\
\text { negative evaluation “-” }\end{array}$ & Sums probability \\
\hline 1 & Ethics & 0.067 & 0.174 & 0.241 \\
2 & Knowledge & 0.103 & 0.054 & 0.157 \\
3 & Labor & 0.107 & 0.044 & 0.151 \\
4 & Speech & 0.038 & 0.079 & 0.117 \\
5 & Family & 0.062 & 0.038 & 0.1 \\
6 & Health & 0.026 & 0.06 & 0.086 \\
7 & Food & 0.065 & 0.018 & 0.083 \\
8 & Wealth & 0.035 & 0.03 & 0.065 \\
& Sums & 0.503 & 0.497 & 1 \\
\hline
\end{tabular}

A more vivid presentation of the data can be achieved in the form of two diagrams (Figure 4). 

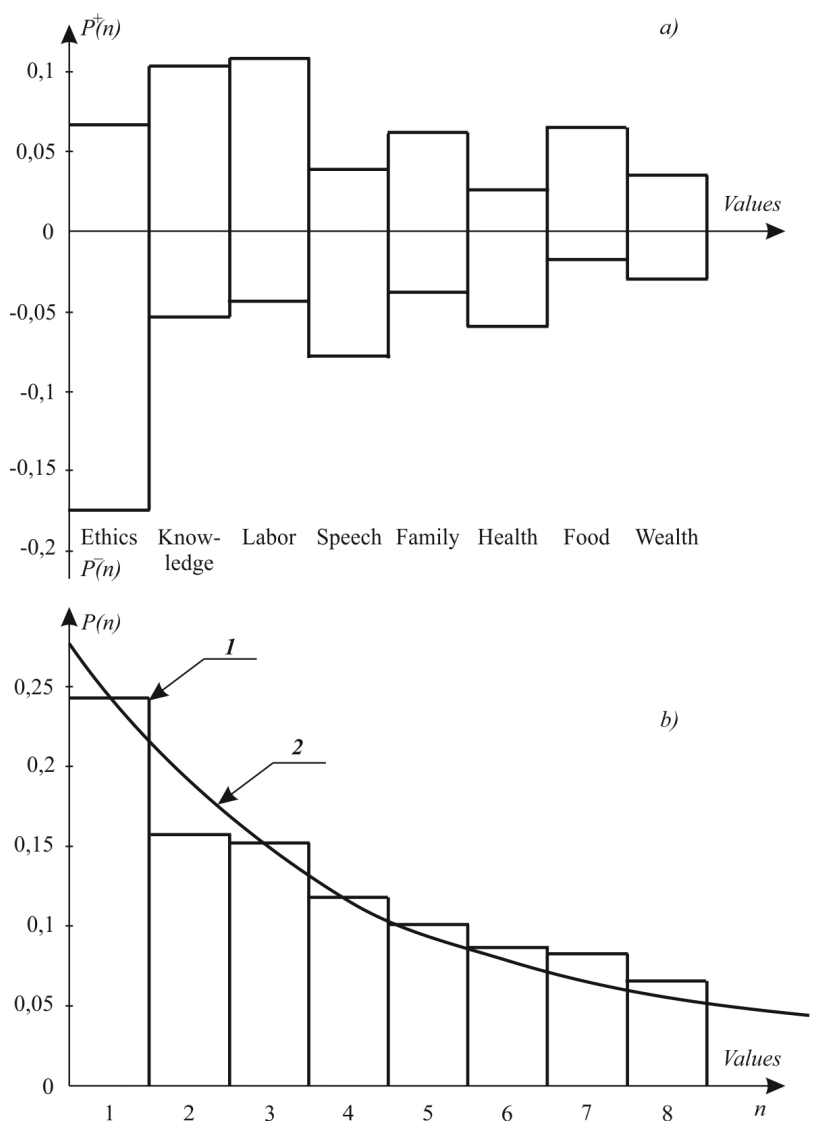

Figure 4. Differential (a) and summarizing (b) diagrams showing the averaged value-mention probability distribution in Udmurt proverbs and sayings

Ethics, knowledge and labor constitute the main value group. People condemn vices and moral flaws such as: laziness (Азьтэм муртльишундыё куазь но жоба "A windy day is a rainy day for an idler"), stupidity (Визьтэм йыр тӧлъя ветлэ "A stupid head flies in the wind"), violence, aggression (Атасэн атас уз тупалэ “A rooster will never get along with a rooster"), greed (Узыр мурт корт кӧжы кадь чурыт (котьку но чурыт) "A rich man is as hard as iron peas ( always avaricious)", heavy drinking (Вина ке сюриз, нянь но кулэ ӧвӧл "If you get wine you don't need any bread"), cowardice (Кьикась мурт ас вужерезлэсь но кыикка "A coward is afraid of his own shadow"), theft (Вор пайдалы уг лушкаськы "A thief steals without profit"), епvу (Муртлэн азбараз пудоез но кӧйгес "Cattle are fatter in other people's sheds" "На чужом дворе и скот жирнее"), ingratitude (Сылалэн нянь пунэмо "Borrowed bread and salt should be repaid").

The second place is occupied by the factor "Knowledge". The Komis think that "Адями вань ультозяз визь люка "It is never too late to learn". There is a connection between skills and knowledge: Быгатон-тодон бордын "Skills are knowledge". Despite poverty and need, people should strive to acquire knowledge: Пьцад кут ке но мед луоз, йырад тодэмэд мед луоз lit. "Your feet can be in bast-shoes, but in your head there must be knowledge". People understand that: Визьлы базаре уг ветло "You can't go the market to get knowledge".

Proverbs and sayings denoting the value of labor are next in order of frequency. They show ties of labor with food: Гырыны ке ӧд аналскы, нянё луод "If you are not too lazy to plough you will have bread" "Кин муи возе, чиньыоссэ нюлэ "Тhose who keep bees lick their fingers", Пылдэ ке ӧд коты, чорыг но уд куты "If you do not wet your feet you will not catch fish". Life for Udmurt peasants was a fight for survival as agriculture brought little profit because of unfavorable climate conditions. You need experience for choosing a suitable system of land utilization. Peasants sowed rye, barley, and oats. Proverbs and sayings reflect a peasant's hard labor: Гырись геры сыномыны уг сётскы "A plough will not get rusty in a ploughed field"; Вӧй ке сиемед потэ, тросгес сюйын погылляськы "If you want to eat butter you should work more in the ground"; Герыез ке яратӥд, нянё луод "If you like the wooden plough you will have bread"; Дӧдьыдэ дася гужем, нош 
урободэ-толалтэ "Get a sledge in summer, and a cart in winter"“. Proverbs underline the fact that only those who work hard know the price of their prosperity: Кин ачиз уг ужа, уксёлэсь дунзэ уг тод "Не who does not earn money himself, does not know its value of it".

\section{Discussion}

Values serve as everyday guidelines in objective and social reality. As a result of this investigation it turns out that the ethnic groups under study share eight common values: ethics, knowledge, family, labor, speech, food, wealth, and health. They proved to be such broad notions that they allowed the inclusion of some additional shades of conceptual meanings. Thus wealth is associated with money, gold, land, trade and thrift. Absence of wealth is shown by such notions as poverty, need, grief, wastefulness, and peonage. Health in people's perception is associated with youth, beauty, cleanliness, longevity, strength and vigor. Its antithesis - sickness - is connected with old age, filth and the path to death. Knowledge in folklore aphorisms are expressed through wisdom, quick wit, skills, and can be acquired in the family, traveling, at school, by reading books and newspapers.

Concluding the description of the Finno-Ugrians' values we tabulate the data in Averaged Probability Distribution of Values in Eastern Finno-Ugrians' proverbs Table 5.

Table 5. Averaged probability distribution of values in proverbs and sayings of Eastern Finno-Ugrians

\begin{tabular}{clccc}
\hline No & Value & $\begin{array}{c}\text { Probability of usage } \\
\text { with positive evaluation } \\
\text { “+” }\end{array}$ & $\begin{array}{c}\text { Probability of usage with } \\
\text { negative evaluation } \\
\text { “_” }\end{array}$ & $\begin{array}{c}\text { Total } \\
\text { probability }\end{array}$ \\
\hline 1 & Ethics & 0.081 & 0.15 & 0.231 \\
2 & Knowledge & 0.099 & 0.044 & 0.143 \\
3 & Family & 0.09 & 0.044 & 0.134 \\
5 & Labor & 0.08 & 0.043 & 0.123 \\
7 & Speech & 0.049 & 0.068 & 0.117 \\
6 & Food & 0.073 & 0.02 & 0.093 \\
4 & Wealth & 0.046 & 0.04 & 0.086 \\
8 & Health & 0.03 & 0.043 & 0.073 \\
& & 0.548 & 0.452 & 1 \\
\hline
\end{tabular}

The research results which are shown in Table 5 are graphically represented in Figure 5. 

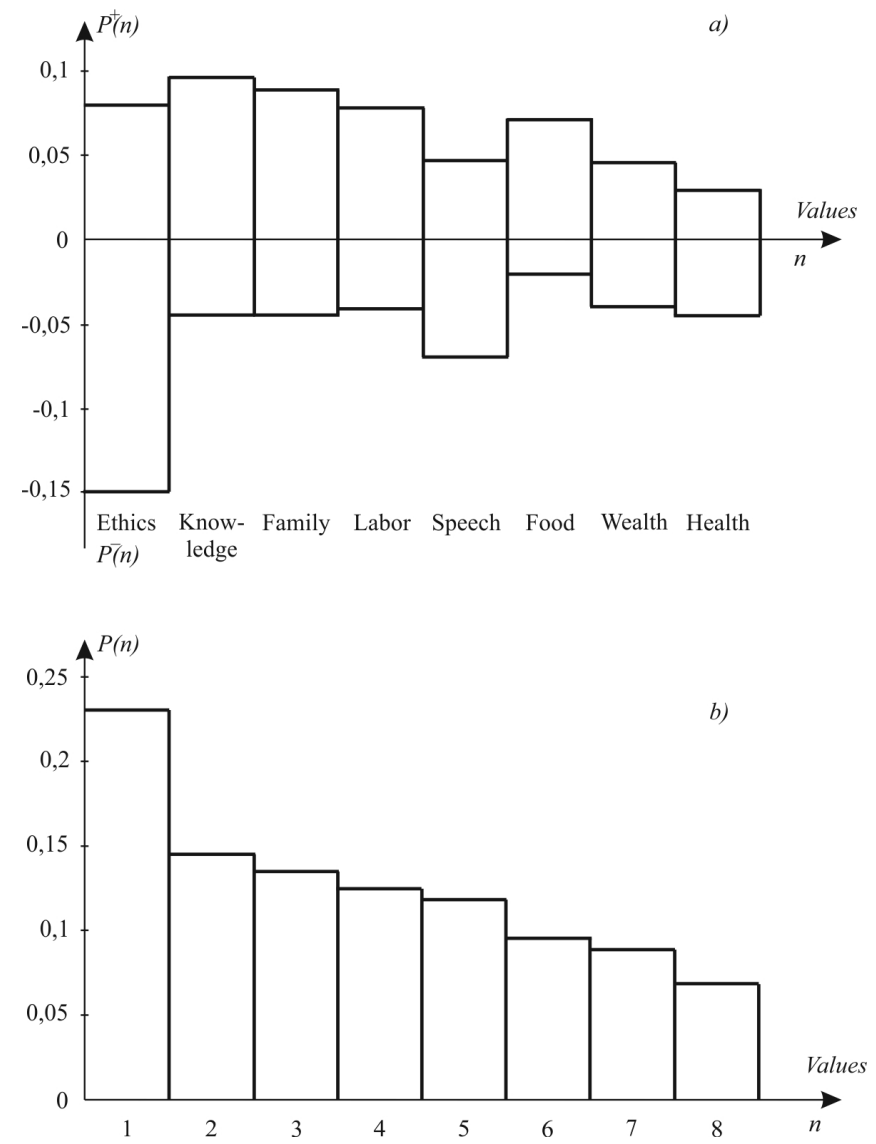

Figure 5. Averaged diagrams of value mention probability distribution in Eastern Finno-Ugrians proverbs and sayings: a) differential, b) summarizing

The proverbs and sayings analyzed have shown that "Ethics" permeates nearly all aspects of human life, showing systemic ties with other values. It is understood as a strict hierarchy with an accent on respect to elder men in the clan. The proverbs and sayings analyzed showed subordination of women to men, and, children to adults. Finno-Ugrians criticize people for being aggressive, lazy, greedy, dishonest, ignorant, ungrateful, envious etc.

The second main factor is "Knowledge", which is defined positively. Finno-Ugrians value knowledge so highly because of their traditional patterns of life where the knowledge of nature and climatic conditions was useful supporting the normal life of all members of an extended family.

"Family" and "Labor" are the next factors that are held in high esteem. In subsistence economies the members of the big extended family work together for their mutual benefit. The figures of their averaged probability of usage are very close and they show the systemic effect of the efforts of all family members, working for the clan.

The fifth place on the diagram is occupied by the factor "Speech" which is described "neutrally" with a slight predominance of the negative evaluation.

"Food" is on the sixth place on the diagram. The positive connotation of this factor allows us to assume that Finno-Ugrians did not experience hunger and that they could find sufficient "daily bread" for a modest existence.

The seventh place of "Wealth" clearly shows that the Finno-Ugrian ethnic groups under study lack the disposition for being greedy and having a spirit of acquisitiveness. Their attitude towards wealth is neutral.

The factor "Health" occupies the eighth place which raises the question why health is hardly considered a value at all. In the proverbs analyzed the mention of disease and death is much more frequent than the recording of health and vigour. The supposition that everybody was healthy is not logical. It remains only to be said that lack of concern about health care is a typical feature of the Finno-Ugrians. The reason probably lies deep in the ethnic subconscious. 
The averaged diagram reveals the following facts: (1) The rank factor place testifies to the importance of the shown value for the ethnic group. If the probabilities of two factors are nearly equal, statistics in this case explains that they are logically connected with one other. (2) The ratio of heights of "positive" and "negative" columns within one factor shows the evaluation of this factor by the ethnic groups. The estimation may be positive, negative, or neutral. (3) The ratio of the sums of heights of all "positive" and "negative" columns characterizes the predominance either of positive or negative evaluation of different life aspects by a given ethnic group and can be calculated.

The presence of these three informative parameters, applied to the eight-factor diagrams, allows the authors to reveal the differences among ethnic value systems. The introduction of a linear correlation coefficient can help define a degree of relatedness between Finno-Ugrian value systems quantitatively through pairing.

In the humanities the quantitative characteristics (similarity and difference) are predominantly defined with the help of linguistics parameters of membership function on the scale of quality. The quantitative evaluation of quality is expressed by such lexemes as "bad", "satisfactory", "good" or "excellent". A linguistic variable characterizes the quality by the following words: very-very poor, very poor, below average, average, above average, good, very good, high, very high, very-very high (Belov, 2003, pp. 203-204).

For the quantitative assessment of Finno-Ugric cultural affinity we use the linear correlation coefficient $r$ which is successfully employed in mathematical statistics to measure the degree of similarity between two sets of random variables. Its value ranges between -1 and 1 . The coefficient is used for stochastic processes (the humanities and social sciences) and can measure the strength of association between two variables. Depending on its value there are the following types regarding the strength of association between the compared objects: "zero", "weak", "moderate", "strong" or, "maximum". Zero means there is no linear correlation between the two variables. If the coefficient is close to 1 we can speak of a strong linear relationship meaning close association of two variables. A correlation greater than 0.5 is considered strong, whereas a correlation less than 0.5 is considered weak.

In this paper the correlation coefficient is calculated according to the formula:

$$
r=\frac{n \sum_{i=1}^{n} x_{i} y_{i}-\left(\sum_{i=1}^{n} x_{i}\right)\left(\sum_{i=1}^{n} y_{i}\right)}{\sqrt{n \sum_{i=1}^{n} x_{i}^{2}-\left(\sum_{i=1}^{n} x_{i}\right)^{2}} \cdot \sqrt{n \sum_{i=1}^{n} y_{i}^{2}-\left(\sum_{i=1}^{n} y_{i}\right)^{2}}}
$$

Where $n$ is a number of members in the row (the number of observations), $x_{i}$ represents numbers of the first row, $\mathrm{y}_{\mathrm{i}}$ shows numbers of the second row, $\Sigma$ is the summation symbol.

As an example we can show the procedure on two imagined ethnic groups $x$ and $y$ where the values have been already ranked.

Table 6. Probability distribution of values in proverbs and sayings of imagined ethnic groups $x$ and $y$

\begin{tabular}{ccccccccc}
\hline $\begin{array}{c}\text { Number } \\
\text { Value }\end{array}$ & 1 & 2 & 3 & 4 & 5 & 6 & 7 & 8 \\
& Ethics & Knowledge & Speech & Wealth & Family & Food & Health & Labor \\
\hline Probability distribution, ethnos $x$ & 0.26 & 0.17 & 0.15 & 0.12 & 0.1 & 0.08 & 0.07 & 0.05 \\
Probability distribution, ethnos $y$ & 0.16 & 0.14 & 0.25 & 0.15 & 0.06 & 0.06 & 0.11 & 0.07 \\
\hline
\end{tabular}

The correlation coefficient is calculated in two stages. First we determine interim variables.

$$
\sum_{i=1}^{8} x_{i}^{2}=0,2884 \sum_{i=1}^{8} y_{i}^{2}=0,219 \quad \sum_{i=1}^{8} x_{i} y_{i}=0,197 \quad \sum_{i=1}^{8} x_{i}=1 \quad \sum_{i=1}^{8} y_{i}=1
$$


As a result we get:

$$
r=\frac{8 \cdot 0,197-1}{\sqrt{8 \cdot 0,2884-1} \cdot \sqrt{8 \cdot 0,219-1}}=\frac{0,575}{1,14 \cdot 0,87}=0,58
$$

The value of $r=0.5$ means that the systems have a moderate positive correlation.

This algorithm was applied to the four Finno-Ugrian groups and the results are shown in Table 7.

Table 7. Linear correlation coefficients of value systems in Eastern Finno-Ugrian proverbs and sayings

\begin{tabular}{|c|c|c|c|c|}
\hline & 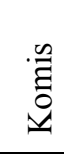 & $\sum_{\Sigma}^{\infty}$ & 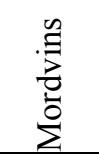 & 司 \\
\hline Komis & & 0.89 & 0.867 & 0.828 \\
\hline Maris & & & 0.889 & 0.796 \\
\hline Mordvin & & & & 0.93 \\
\hline
\end{tabular}

Udmurts

All correlation coefficients exceed 0.5 which testifies to a very close relatedness of the values systems.

\section{Conclusion}

The complex algorithm of the research, which included semantic analysis as well as quantitative evaluation methods, applied to proverbs and sayings, revealed the most important eight values common to the four eastern Finno-Ugrian ethnic groups under study. These values are arranged in a descending order of their frequency of mention. The findings of the investigation are presented as the tabulated data and in the form of two diagrams - differential and summarizing.

Though the number of values is not large these factors can be reduced further into a priority group. Three values - ethics, knowledge and labor - exceed 50\% and represent the reconstructed core of Eastern Finno-Ugric cultural affinity as evidenced in folklore material.

Introduction of value occurrence probability allows calculation of correlation coefficients revealing the degree of closeness and the strength of association among the value systems of the Finno-Ugrians under study. All correlation coefficients are very close to 1 . This fact allows us to speak of a strong linear correlation meaning very close relatedness of the traditional values systems of Eastern Finno-Ugrians.

\section{Acknowledgments}

The article has been written in the framework of the project supported by the Russian Humanitarian Scientific Foundation, grant No.14-04-00043.

The authors of the paper would like to thank Timothy Riese for proofreading and editing the English text.

\section{References}

Belov, P. G. (2003). Systemic Analysis and Modeling of Hazardous Processes in the Technosphere. Moscow: Academia.

Chuzaev, R. I. (2012). Ethnology. Yoshkar-Ola: Mari State University.

Chuzaev, R. I. (2011). To the problem of traditional culture structure changes in the 20-30s of the XX century. Socio-cultural development of Marii El: History and contemporary processes. In Proceeding of All-Russia Scientific Conference (pp. 76-79). Yoshkar-Ola: Mari State University.

Glukhov, V. A., \& Glukhova, N. N. (2011). Finno-Ugric Cultural Affinity: New Approaches to its Research. In A. Haas \& P. B. Brown (Eds.), The Uralic World and Eurasia: Proceedings of the XIVth, XVth, and XVIth 
Conferences of the Finno-Ugric Studies Association of Canada (pp. 49-58). Providence, Rhode Island, the United States: Rhode Island College.

Glukhov, V. A., \& Glukhova, N. N. (2012a). A System of Techniques and Stratagems for Outlining a Traditional Ethnic Identity. A Special Issue of Retrospective Methods Networks Newsletter, 4, 60-72. Retrieved from http: //www.helsinki.fi/folkloristiikka/English/RMN/index.htm

Glukhov, V. A., \& Glukhova, N. N. (2012b). Systemic Reconstruction of Mari Ethnic Idenity. In C. Hasselblatt \& A.van der Hoeven (Eds.), The Finno-Ugric Contribution to International Research on Folklore, Myth and Cultural Identity: Proceedings of the Fifth International Symposium on Finno-Ugric Languages in Groningen (pp. 45-62). Maastricht, the Netherlands: University of Groeningen.

Glukhova, N. N., \& Kudryavtseva, R. A. (2013). Ethnic Mari Values. Historical, Philosophical, Political and Law Sciences, Culturology and Study of Art. Issues of Theory and Practice, 4(1), 44-47. Retrieved from http://www.gramota.net/materials/3/2013/4-2/10.html

Grachyova, F. T. (2001). Hill Mari Proverbs, Sayings, Riddles, Weather Signs. Yoshkar-Ola: Mari State University.

Ibatov, S. I. (1960). Mari Proverbs, Sayings, Riddles. Yoshkar-Ola: Mari Publishing House.

Kang, N. (2009). Puritanism and Its Impact upon American Values. Review of European Studies, 1(2), 148-151. http://dx.doi.org/10.5539/res.v1n2p148

Kitikov, A. E. (2004). Proverbs and Sayings of Finno-Ugrians. Yoshkar-Ola: Mari Publishing House.

Kohls, R. (2011). The Values Americans Live By. Retrieved from http://www. uri.edu/mind/VALUES2.pdf

Paczolay, G. (1987). A Comparative Dictionary of Hungarian-Estonian-German-English-Finnish and Latin proverbs -With an appendix in Cheremis and Zyryan. Veszprém: Veab.

Perevozchikova, T. G. (1987). Udmurt Folklore: Proverbs, Maxims, Sayings. Ustinov: Udmurtia.

Plessovskii, F. V. (1983). Komi Proverbs and Sayings. Syktyvkar: Komi Publishing House.

Popkov, Yu. V. (2009). Basic values of people of the Euroasian civilization in the conditions of globalization. In Electronic News Magazine-The New Research of Tuva (pp. 1-2). Retrieved from http://www.tuva.asia/index.php?newsid=95

Samorodov, K. T. (1967). Mordvin Paremiology (Vol. 4, book 1). Saransk: Mordva Publishing House.

Shabykov, V. I. \& Kudryavtseva, R. A. (2014). Mother Tongue as an Ethnic Value of the Mari (gender aspect). Historical, Philosophical, Political and Law Sciences, Culturology and Study of Art-Issues of Theory and Practice, 8(2), 204-207. Retrieved from http://www.gramota.net/materials/3/2014/8-2/53.html

Shkalina, G. E. (2003). Traditional Mari Culture (2nd ed.). Yoshkar-Ola: Mari Publishing House.

Shkalina, G. E. (2012). Ethnic ethical aspects in Mari traditional outlook. Bulletin of Kazan State University of Culture and Arts, 3, 48-53.

Williams, Jr., \& Robin. (1970). U. S. Value List. Retrieved from http://stmarys.ca/ evanderveen/wvdv/class_relations/us_values_list.html

\section{Copyrights}

Copyright for this article is retained by the author(s), with first publication rights granted to the journal.

This is an open-access article distributed under the terms and conditions of the Creative Commons Attribution license (http://creativecommons.org/licenses/by/3.0/). 